timber have engaged the attention of Dr. A. J. Du Toit, research officer, Timber Unit, South African Council for Scientific and Industrial Research, Pretoria, who has published a paper, The Use of Timber as a Building Material in Hot Climates (National Building Research Institute. Reprinted from RILEM Bulletin No. 25 , December 1964. Council for Scientific and Industrial Research. Ref. No. RU I.13). Dr. Du Toit points out that, in Africa, two types of hot conditions can be distinguished, the arid hot type, such as is encountered in the region between Timbuktu and Agadès, and the humid hot type in the region between Douala and Abidjan. The average temperature in both these regions is approximately $80^{\circ} \mathrm{F}$, while the average humidity is approximately 35 per cent in the dry region and 83 per cent in the humid rogion. Obviously wood, being a hygroseopic material, will react quite differently in these contrasting climates. The theme of this paper is that wood can only givo satisfactory service as a building material if its properties and behaviour in varying circumstances are known and well understood. There exists a certain amount of prejudice against the use of timber as building material in tropical countries, but this may be partly duo to lack of knowledgo of its reactions in such environments on the part of builders. It is considered that correct application of present-day knowledge of the properties and behaviour of various woods under tropical conditions would do much to overcome this prejudice. Such information includes primarily climatic agents: the effects of temperature, humidity, rain, exposure to sun, evaporation, dust storms, cyclical influences, maritime influences, direct effects of sea-water (continuous or alternating immersion), saline atmosphere, spray; and biological agents: cryptogams (rot, mould, algae, lichens, fungi), insects (termites, borers, etc.), and vegetation. Dr. Du Toit discusses all these agents, and his paper contains much practical advice on ways and means of protection of timber exposed to these potentially destructive forces, including notes on various West African woods considered to be resistant at least to some of them.

\section{Progress in Protozoology}

THE second international conference on "Protozoology", held in London during July-August 1965, discussed many aspects of this subject. Protozoologists the world over will welcome the publication of abstracts of the many papers read at the Conference, entitled Progress in Protozoology (Abstracts of Papers read at the Second International Conference on Protozoology, London, July 29August 5, 1965) (International Conference Series, No. 91. Pp. 278. Amsterdam, New York, London, Milan, Tokyo and Buenos Aires: Excerpta Medica Foundation, 1965. 65s.). Prefaced by a message of welcome and goodwill from Prince Philip, the volume discusses so many aspects of the biology, morphology and ecology of a wide variety of Protozoa that it is impossible to summarize its contenis in a brief note. An idea of the number and variety of tho papers read may be gained from the fact that the index of authors belonging to many nationalities covers two pages, each with four columns of names.

\section{Antimalarial Prophylaxis in Eastern Nigeria}

Everyone concerned with the world-wide campaign against malaria, a disease that was once aptly described as 'public enemy No. 1', will be interested in Dr. Hay Arthur's account of antimalarial prophylaxis in primary schools in Eastern Nigeria (Antimalarial Prophylaxis in Primary Schools in Eastern Nigeria. February-March, 1965. Pp. 41. London: Wollcome Museum of Medical Research, 1965). Dr. Arthur shows that in the suburbs of a town in Eastern Nigeria, where one out of every two children is infected with malaria, the number of children suffering from the disease can drastically be reduced by a regular weekly dose of 'Daraprim'.

\section{Human Intelligence}

Some reasons why the evolution of human intelligence should be a continuing process have been described by Prof. Sheldon C. Reed, director of the Dight Institute of Human Geneties at the University of Minnesota. When parents' income, education, social status, or I.Q. is correlated with the number of children they produce, correlation coefficients are obtained which are negative in sign. These well-established negative correlations aro statistically biased and seriously misleading, because they ignore the important segment of the parental generation which had no ehildren. The negative correlation $(-0 \cdot 30 \pm 0 \cdot 02)$ between family size and intelligence of the children in it has no meaning for the next generation. because the mentally retarded children will have little income, education or social status; they will seldom marry or have offspring. The mentally retarded who do produce may have large families, but the average number of children produced by the retarded is lower than that of normal persons. It is impossible to determine what is happening to the intelligence of mankind as a whole, but it is clear that it is not decreasing at an approciable rate. Prof. Reed's main conclusion is the perhaps euphoric concept that genetic orthoselection for higher intelligence is continuing at the present time. The challenge of is complex world, with an ever greater premium placed on higher intelligence, should result in an acceleration of the rate of evolution toward that end (American Scientist, September 1965).

\section{International Commission on Zoological Nomenclature}

Notice is hereby given of the possible use of its plenary powers by the International Commission on Zoological Nomenclature in connexion with the following cases, full details of which will be found in the Bulletin of Zoological Nomenclature (22, Part 3; November 2, 1965): (1) Suppression of Drassus atropos Walckenaer, 1830 (Aranea). (2) Validation of Pan and Panthera from Oken, 1816 (Mammalia). (3) Neotype for Ceratophyllus soricis Dale, 1878 (Insecta, Siphonaptera). (4) Suppression of Eucidaris P'omel, 1883, Papula Bayle, 1878, Cidaris papillataconoidea Parkinson, 1811, and Cidarites savignyi Audouin, 1826 (Echinoidea). (5) Type-species for Phasia Latreille, 1804 (Insecta, Diptera). (6) Suppression of Papilio lintingensis Osbeck, 1765 (Insecta, Lepidoptera). (7) Typo-species for Monopsyllus Kolenati, 1875; suppression of Geratopsyllus sciuri Kolenati, 1856, Monopsyllus sciuri Kolenati, 1857, and Ceratopsyllus monoctenus Kolenati, 1856 (Insecta, Siphonaptera). (8) Type-species for Stizus Latreille, [1802-1803] (Insecta, Hymenoptera). (9) Type-species for Diodontus Curtis, 1834 (Insecta, Hymenoptera). (10) Typespecies for Trychosis Foerster, 1868 (Insecta, Hymenoptera). (11) Type-species for Prospaltella Ashmead, 1904 (Insecta, Hymenoptera). (12) Suppression of Mullus auriflamma Forskal, 1775 (Piscos). (13) Type-species for Chamaemyia Meigen, 1803 (Insecta, Diptera). (14) Suppression of Xyleborus Bowdich, 1825 (Insectia, Coleoptera). Any zoologist who wishes to comment on any of the foregoing cases should do so, in writing, within five months, to the Secretary, International Corrmission on Zoological Nomenclature, c/o British Museum (Natural History), Cromwell Road, London, S.W.7, England. Those received early enough will be published in the Bulletin of Zoological Nomenclature.

\section{Selective Control of Weeds in Rice Fields}

IN vast areas of the world, rice is tho basic food crop. There are as many differont varieties of rice as there are different ways of growing it; but wherever it is cultivated, weed control has always been, and still is, a primary concern of the rice grower. The most univorsally prevalent and troublesome weed to contend with in rice fields is what is known as barnyard grass; this is so much like rice that even experienced farmers find some difficulty in 